\title{
E-GOVERNMENT AND SECURITY OF INFORMATION INTERNET SOURCES
}

\section{E-GOVERNMENT AND SECURITY OF INFORMATION RELATED PUBLICATIONS}

\section{GENERAL PUBLICATIONS}

\section{U.S. e-Government Strategy}

http://www.whitehouse.gov/omb/inforeg/egovstrategy.pdf

The U.S. e-Government Strategy was published on 27 February 2002. It presents the federal government's action plan for e-Government. The primary goals for the U.S. President's "Expanding E-Government" initiative are to:

- Make it easy for citizens to obtain service and interact with the federal government;

- Improve government efficiency and effectiveness; and

- Improve government's responsiveness to citizens.

OMB Director Mitchell E. Daniels initiated an interagency E-Government Task Force to identify the action plan for implementing the President's E-Government initiative. The Task Force was made up of about 80 federal employees from across the federal government.

\section{BSI's E-Government Manual}

http://www.bsi.bund.de/fachthem/egov/ http://www.e-government-handbuch.de

These sites provide up-to-date information from Das Bundesamt für Sicherheit in der Informationstechnik (BSI) on the subject of "Secure e-Government," and the latest version of the E-Government Manual. 
Australia - Better Services, Better Government - The Federal Government's eGovernment Strategy

http://www.noie.gov.au/publications/NOIE/better_services-better_gov/index.htm

A framework for the next stage of e-government was launched on 11 November 2002 by Minister for Communications, Information Technology and the Arts, Senator Richard Alston. Better Services, Better Government is a high level e-government strategy designed to outline broad directions and priorities for the future of e-Government. It seeks to maintain the momentum of the achievements under the Government Online Strategy.

\section{Canada - Government On-Line: Serving Canadians in a Digital World}

http://www.gol-ged.gc.ca/pub/serv-can/serv-can00_e.asp

Government On-Line is the plan that supports the Prime Minister's commitment to make the Government of Canada the most electronically connected government in the world to its citizens by 2004 and provide Canadians with electronic access to federal information and services.

\section{United Kingdom Online Strategy}

http://e-government.cabinetoffice.gov.uk/Homepage/fs/en

This Strategy is the UK Government's comprehensive programme to lead the knowledge economy revolution, and how the Strategy is managed.

\section{New Zealand E-government Strategy 2001 and 2003}

http://www.egov.vic.gov.au/pdfs/egovt-strategy.pdf

http://www.e-government.govt.nz/docs/e-gov-strategy-june-2003/index.html

http://www.e-government.govt.nz/docs/e-gov-strategy-june-2003/strategy-2003-complete.pdf

On 26 April 2001, the NZ Government launched the e-Government Strategy, which sets out an operational vision for e-government: that New Zealand will be a world leader in e-government.

\section{eEurope 2005 - A Study of the Degree of Alignment of the New Member States and the Candidate Countries}

http://www.dree.org/elargissement/RapportsSite/INSEADeEuropeCompar0408.pdf 
This study prepared by INSEAD for SAP measures the alignment of the new EU Member States and the candidate countries with the 'old' members with regard to the objectives set in the eEurope 2005 Action Plan. This measurement is based on the eEurope 2005 Index, a composite indicator of the level of development of the Information Society incorporating five dimensions: general Internet indicators, modern online public services, dynamic e-business environment, secure information infrastructure, and broadband. Based on their performance in these fields, four categories of countries were identified according to their alignment with the average score of the 15 'old' Member States: 'Global Leaders', 'Totally Aligned', 'Somewhat Aligned', and 'Development required'.

\section{European Interoperability Framework for pan-European e-Government Services}

http://europa.eu.int/idabc/en/document/3761

http://europa.eu.int/idabc/servlets/Doc?id=18952

The EIF is the reference document on interoperability for the IDABC program. It is the result of an extensive consultation process with the Member States and thus represents the highest ranking module for the implementation of European e-Government services. This first version provides a series of recommendations and defines generic standards with regard to organizational, semantic and technical aspects of interoperability, offering a comprehensive set of principles for European co-operation in eGovernment. More information about the EIF related activities of the IDABC program can be found at: http://europa.eu.int/idabc/en/document/2319/5644.

\section{U.S. Department of Labor e-Government Strategic Plan}

http://www.dol.gov/_sec/e_government_plan/p23_security_privacy.htm

This document focuses on development of U.S. Department of Labor's e-Government security and privacy framework, implementation of PKI, and assessment of the impact of privacy issues related to IT systems.

\section{U.K. e-Government Interoperability Framework}

http://www.govtalk.gov.uk/schemasstandards/egif.asp

The e-Government Interoperability Framework (e-GIF) defines the technical policies and specifications governing information flows across government and the public sector. They cover interconnectivity, data integration, e-services access and content management. Version 6.0 contains the high level policy statements, management, im- 
plementation and compliance regimes, whilst technical policies and specifications are contained in the Technical Standards Catalogue. This document was created by the U.K. Cabinet Office, e-Government Unit, Technology Policy Team, Interoperability Policy Advisor and published on 19 August 2004.

\section{U.K. e-Service Development Framework}

http://www.govtalk.gov.uk/schemasstandards/eservices_document2.asp?docnum=515 The e-Service Development Framework provides a structure for developing semantic specifications and standards for e-Services. An e-Service is any electronic service involving interoperability between computer systems. This is Version 1.0 of the document, published on 12 May 2001.

\section{E-Government Leadership - Realizing the Vision}

http://www.accenture.com/xd/xd.asp?it=enweb\&xd=newsroom/epresskit/egov/epres_ realizing.xml

http://www.accenture.com/xdoc/en/industries/government/egov_april2002_3.pdf

National governments throughout the world significantly improved their online service delivery, increasing the range and sophistication of e-Government services for citizens and businesses alike, according to Accenture's third annual global eGovernment study. As governments progress along the e-Government path, they also are demonstrating greater understanding of technology's potential to help fully transform the way they operate - both in terms of service delivery and administrative effectiveness. This Accenture Report looks in detail at findings from 23 countries. Accenture looks at progress made in these countries since its previous study conducted in 2001. The report also shows numerous examples of best practices in several government service sectors.

\section{Papers by Janet Caldow, Director, Institute for Electronic Government, IBM Corporation}

http://www-1.ibm.com/industries/government/ieg/library/papers.html

- Seven E-Government Leadership Milestones As electronic government comes of age around the world, leadership remains at the core of success, beginning with the definition of e-government itself (http://www1.ibm.com/industries/government/ieg/pdf/Seven_E-Gov_Milestones.pdf).

- e-Democracy: Putting Down Global Roots As governments achieve more sophisticated levels of e-Government, strategy should include progression to 
more sophisticated levels of e-Democracy within and beyond national borders.

- Lessons from around the World Until leaders are willing to inspire fundamental reform, e-Government will remain unfulfilled - an elusive concept.

- e-Government Goes Wireless: From Palm to Shining Palm Just when you thought you could sit back, relax, and let e-government roll its way onto shore, the next big swell has already formed out there on the Internet high seas. Wireless. Need some proof.

- The Virtual Ballot Box: A Survey of Digital Democracy in Europe Elected representatives today are serving office during a unique period in history - at the threshold of a technological, social, economic, and political transition the likes of which we haven't seen since the Industrial Revolution.

- e-Government: A Go-to-Market Strategy Five years ago, the term "electronic government" was not in our vocabulary. Today, "e-government" has become a battle cry for digital age governments around the world.

- The Quest for Electronic Government: A Defining Vision This paper incorporates good advice from four years' research, literature searches, innovative practices from around the world, emerging strategies and future indicators and trends.

\section{E-Government Enterprise Architecture Guidance (Common Reference Model)}

http://www.feapmo.gov/resources/E-Gov_Guidance_Final_Draft_v2.0.pdf

The purpose of this document is to provide augmenting architectural guidance to the official direction from the U.S. Federal Enterprise Architecture Program Management Office. It is intended to provide a consistent, industry-aligned approach for defining and communicating about the components needed to cost and plan e-Government programs - both the 24 Presidential Priority e-Government Initiatives and other eGovernment Initiatives across the Federal Government.

This document describes a Federal-wide e-Government target conceptual architecture. The architecture is based on the business requirements derived from the initiatives as well as system engineering design best practices. It provides a workable description of the components needed by e-Government Initiatives and business activities to move rapidly into the web service-enabled business transaction environment. This is Version 2.0 of the document, prepared by the FEA Working Group; published on 25 July 2002, and endorsed by the Architecture and Infrastructure Committee, Federal CIO Council. 


\section{E-Government: Connecting the Dots?}

http://www.accenture.com/xdoc/en/industries/government/eGovernmentA4.pdf

This study by Accenture looks at how Governments in Europe are meeting the challenge of re-inventing the business of Government. The report provides insights into executives' attitudes to e-Government - what private sector executives want from eGovernment and the challenges and opportunities public sector executives perceive as they seek to deliver on the promise of e-Government.

\section{Electronic Governance: Re-inventing Good Governance}

http://www1.worldbank.org/publicsector/egov/Okot-Uma.pdf

A paper written by Rogers W'O Okot-Uma, Commonwealth Secretariat, London. The paper includes a discussion of different types of e-Government applications and some country experiences.

\section{E-Government Best Practice Examples from Austria, Germany and Switzerland} http://www1.worldbank.org/publicsector/egov/egovbestpractice.pdf

The paper discusses some small service oriented projects that show how value can be delivered to citizens via small pilot projects.

\section{Roadmap for E-government in the Developing World}

http://unpan1.un.org/intradoc/groups/public/documents/other/unpan006407.pdf

The paper poses ten questions e-government leaders should ask themselves. It is prepared by the Working Group on e-Government in the Developing World; April 2002.

\section{The Information Society: The Role of Information in the Emerging Global e- Government, e-Governance and e-Democracy Environments}

http://www.electronicgov.net/pubs/research_papers/tracking03/IntlTrackingReporttA pr03no3.pdf

International Tracking Survey Report '03, Number Three, by Thomas B. Riley, Chair and Executive Director, Commonwealth Centre for Electronic Governance, Visiting Professor, University of Glasgow, President, Riley Information Services. Prepared under the auspices of the Commonwealth Secretariat and co-sponsored by Government Telecommunications and Informatics Services, Public Works and Government Services Canada, April 16, 2003. 


\section{Latin America's e-Government Sites}

http://www1.worldbank.org/publicsector/egov/LA_EGovSites.doc

The document classifies federal, state, and local government websites in Argentina, Brazil, Colombia, and Mexico along three dimensions: search (general vs. specific), communication (one-way vs. interactive), and type of linkage (between different levels of government or horizontal).

\section{Global e-Government Report 2004}

http://www.insidepolitics.org/egovt04int.html

A report by Darrell M. West, Center for Public Policy, Brown University, Providence, Rhode Island 02912-1977, United States. This study highlights how eGovernment has developed around the world. It analyses 1935 government websites in 198 different countries. It also highlights the various developments taking place across specific regions and countries.

\section{Publications on Enabling e-Government of the Center for Technology in Government}

http://www.ctg.albany.edu/publications/publications?sub=egov

- Return on Investment in Information Technology: A Guide for Managers (August 2004) New information technology (IT) systems are serious, and potentially risky, investments for government agencies and nonprofit organizations. This guide is designed to help public sector managers better understand how a return on investment (ROI) analysis can take some of that risk out of their next IT investment.

- Untangle the Web: Delivering Municipal Services through the Internet (December 2002) The Web offers people and organizations a new way to interact and communicate. This report provides a framework for helping local governments achieve the benefits of the Web without being overcome by its complexity.

- Making a Case for Local E-Government (July 2002) Local and county governments are exploring the best ways to implement e-Government. This report details the strategies, funding, barriers, and benefits brought to bear by several New York State local e-government pioneering initiatives, with insight and advice for their colleagues.

- And Justice for All: Designing Your Business Case for Integrating Justice Information (May 2000) Efforts to improve public safety in the United States 
are pointing to an increasing need for justice agencies to share information. This guidebook offers a series of lessons and tools justice officials can use to build business cases to win support and funding for integrated justice information systems.

- Highlights: Exploring the Feasibility of a Digital Government Journal (July 2004) This project administered an online survey exploring the opinions and preferences of the digital government (DG) research community with respect to the need for, feasibility, and sustainability of a dedicated digital government journal.

- The New York State-Local Internet Gateway Prototype Project: Current Practice Research (July 2004) In the fall of 2002, the Center for Technology in Government (CTG) at the University at Albany conducted current practice research to identify and examine existing government to government $(\mathrm{G} 2 \mathrm{G})$ portal projects.

- Bridging the Enterprise: Lessons from the New York State-Local Internet Gateway Prototype (May 2004) This project report details the Gateway Prototype project from conceptualization and development to findings and recommendations. The Prototype was developed to create a single point of contact among state and local governments to test and evaluate mechanisms for government-to-government (G2G) business relationships.

- Creating and Maintaining Proper Systems for Electronic Record Keeping (December 2002) E-Government is changing the way government conducts business and captures records created during that business. This paper provides a framework for developing new e-government systems that foster electronic records management.

- $\quad$ The Future of e-Government (June 2002) This paper is based on testimony presented to the New York City Council on a sustainable definition and model of electronic government.

- What Citizens Want from e-Government (October 2000) Governments in the US are using a variety of methods to find out what citizens want from electronic government services. This report presents those methods, and weighs the pros and cons of each of them.

- Understanding New Models of Collaboration for Delivering Government Services (Communications of the ACM, Volume 46, Number 1, January 2003, pp. 40-42) More and more government agencies are creating collaborative relationships to improve services they provide. This article presents a summary of an international research project that is studying eleven collaborative partnerships developed to deliver government information. 
- Electronic Government: A Vision of the Future that is Already Here (Syracuse Law Review, Volume 52, Number 4, 2002, 1243-1251) Though they may be going unnoticed, e-Government initiatives are changing the way that the public sector works. This article introduces a four-faceted vision of eGovernment and describes some of the ways that it is already changing government.

- Realizing the Promise of Digital Government (IMP Magazine, October 2000) Many of us have already experienced the potential of the Web to change our relationships with other individuals, businesses, and now government. This article discusses the transformation needed before we can realize the promises of electronic government.

- Implications of Legal and Organizational Issues for Urban Digital Government Development (Government Information Quarterly, Volume 18, 2001, 269-278) Legal and organizational issues converge when developing digital government in large urban settings. This paper contends that this convergence is a powerful determinant of how these projects develop and how likely they are to succeed.

\section{The UN Global e-Government Survey 2004}

http://www.unpan.org/egovernment4.asp

The UN Global e Government Survey 2004 presents a comparative ranking of the countries of the world according to two primary indicators: the state of e-government readiness; and the extent of e-participation. Constructing a model for the measurement of digitized services, the Survey assesses the 191 member states of the UN according to a quantitative composite index of e-Government readiness based on website assessment; telecommunication infrastructure and human resource endowment. As countries progress in both coverage and sophistication of their state-provided eservice and e-product availability they are ranked higher according to a numerical classification corresponding to the five stages of Emerging presence, Enhanced presence; Interactive presence; Transactional presence and Networked presence.

\section{PUBLICATIONS ON SECURITY OF INFORMATION}

\section{BSI's IT-Baseline Protection Manual}

http://www.bsi.bund.de/gshb

http://www.it-grundschutzhandbuch.de 
Standard security measures are published in the BSI's IT Baseline Protection Manual. The online version could be found at the above sites.

\section{CSI/FBI Computer Crime and Security Survey}

http://www.gocsi.com/forms/fbi/csi_fbi_survey.jhtml

http://i.cmpnet.com/gocsi/db_area/pdfs/fbi/FBI2004.pdf

The Computer Crime and Security Survey is conducted by the Computer Security Institute (CSI) with the participation of the San Francisco Federal Bureau of Investigation's Computer Intrusion Squad. The survey is conducted by Lawrence A. Gordon, Martin P. Loeb, William Lucyshyn and Robert Richardson. The survey is now in its ninth year and is, according to the authors, the longest-running survey in the information security field. This year's survey results are based on the responses of 494 computer security practitioners in U.S. corporations, government agencies, financial institutions, medical institutions and universities.

\section{ISQ Handbook - Information Security Qualifications}

http://www.isn.ethz.ch/researchpub/publihouse/misc/isq/isq_handbook.pdf

A handbook written by Anna Hess Sargsyan and Edgar Danielyan. The Information Security Qualifications Handbook is a joint initiative between the ISN and its Cooperating Partner Danielyan Consulting LLP. The Handbook offers an in-depth coverage of existing information security qualifications with an objective to introduce EAPC/PfP information security professionals to the most appropriate certification programs for a sustainable education in information security. The ISQ Handbook is a follow-up to the first ISN Partnership for Peace Seminar on Information Security held at the ETH Zurich in August 2003. The Handbook is an integral part of the ISN's continuing efforts to promote and enhance information security through training and education within the framework of Switzerland's commitment to fighting asymmetric threats throughout the Euro-Atlantic Partnership Council region.

\section{Implementing Information Security: Risks vs. Cost}

http://www.cyberguard.info/news_room/e_newsletter_archives.cfm\#

Published in CyberGuard E-Newsletter, June 2004. As a security professional who understands how the business world works, Gideon T. Rasmussen (CISSP, CISM, CFSO, SCSA) wrote this article to convey the imperative need for security professionals and senior management to see eye-to-eye. Being motivated by business, senior management focuses on productivity and the bottom line. It is sometimes difficult to 
calculate a return on investment for security, but the damage caused by the absence of efficient controls is far greater than the cost of implementing them.

\section{Creating Security for e-Government Services}

http://www.checkpoint.com/promoforms/ww/2004/gov2004ww03.html

The site provides free download of "Creating Security for e-Government Services" white paper that helps the reader to learn about U.S. federal laws and guidelines and how to implement stronger security for e-Government services with COTS products.

Protect Privacy and Security: Imperative 5 of "Eight Imperatives for Leaders in a Networked World"

http://www-1.ibm.com/industries/government/ieg/pdf/eightImperative.pdf

A series produced by the Harvard Policy Group on Network-Enabled Services and Government.

\section{E-Government Security for Managers}

http://www.state.ga.us/gta/tips/bill_spernow.pdf

By Bill Spernow, CISSP, Georgia Student Finance Commission; December 4, 2001; Introducing INFOSEC at a State Government Agency: Lessons Learned.

\section{Security Concepts and Requirements of e-Government Sites and other Public Electronic Processes}

http://falcon.ifs.uni-linz.ac.at/research/phd_hof/

From this site the PhD thesis of Sonja Hof can be downloaded. The thesis describes the concept of e-Government and as an example the idea of one-stop Government. Additionally, some of the newer and more innovative methods to achieve security are presented. After pointing out the security requirements, some security solutions are listed and analyzed whether they are useful for an e-Government implementation.

\section{E-Government Case Studies: United Kingdom: e-Government Security} http://unpan1.un.org/intradoc/groups/public/documents/un/unpan008830.pdf

\section{Security - U.K. e-Government Strategy Framework Policy and Guidelines http://www.govtalk.gov.uk/documents/security_v4.pdf}


This document sets out a framework for the expression of security requirements for the procurement and acceptance of e-Government services and their implementation. It also describes the approach to assuring the presence and proper operation of the security countermeasures put in place to meet the security requirements. This is Version 4.0 of the document, published on 7/11/2002.

\section{Government Security and Authentication Guidelines}

http://www.becta.org.uk/page_documents/corporate/events/expert/Sharon_Wiltshire. pdf

By Sharon Wiltshire, Office of the e-Envoy, Becta Security Seminar, $15^{\text {th }}$ October 2002, Coventry.

\section{The ISF's Standard of Good Practice for Information Security}

http://www.isfsecuritystandard.com

The Standard of Good Practice for Information Security is designed to help any organization, irrespective of market sector, size or structure, keep the risks associated with its information systems within acceptable limits. The Standard has been produced by the Information Security Forum. The Standard has been developed using a proven methodology to produce the international benchmark for information security. The Standard is updated every two years, refining proven practices and addressing 'hot topics', such as intrusion detection, information privacy, effective security awareness, e-mail, broadband, wireless communications and PDAs.

\section{BOOKS ON E-GOVERNMENT AND SECURITY OF INFORMATION}

\section{Building the Virtual State: Information Technology and Institutional Change}

http://www.brook.edu/press/books/virtual_state.htm

A book by Jane E. Fountain, Brookings Institution Press, 2001. The book finds that many issues involved in integrating technology and government have not been adequately debated or even recognized. Drawing from a rich collection of case studies, the book argues that the real challenges lie not in achieving the technical capability of creating a government on the web, but rather in overcoming the entrenched organizational and political divisions within the state. Questions such as who pays for new government websites, which agencies will maintain the sites, and who will ensure that the privacy of citizens is respected reveal the extraordinary obstacles that confront efforts to create a virtual state. 


\section{Managing Information and Knowledge in the Public Sector}

http://www.amazon.com/exec/obidos/tg/detail/-/0415204232/qid=1105969300/sr=11/ref=sr_1_1/103-8350796-3556619? v=glance\&s=books

A book by Eileen M. Milner. For the public sector, which is globally the largest employer of people and repository of information, managing information and knowledge is an extremely problematic area to address. The essence of both resources is that they are intangible, their impact and value cannot be measured through traditional accounting methods, yet they are also where the greatest value and potential for improvement is located.

\section{Electronic Governance: An International Comparative Study}

http://www.amazon.com/exec/obidos/tg/detail/-/0850927676/qid=1105987495/sr=12/ref=sr_1_2/103-8350796-3556619? $\mathrm{v}=$ glance \&s=books

A book by Thomas B. Riley and Rogers Okot-Uma, 2005.

\section{Building a Digital Community: A Leadership Guidebook}

http://www-1.ibm.com/industries/government/ieg/pdf/guidelines.pdf

A product of the e-Communities Task Force provides communities with a strategy for utilizing the Internet and communications technologies to improve quality of life and economic vitality.

\section{Delivering the Vision: Public Services for the Information Society and the Knowledge Economy}

http://www.amazon.com/exec/obidos/tg/detail/-/0415241553/qid=1105969300/sr=12/ref=sr_1_2/103-8350796-3556619? v=glance\&s=books

A book by Eileen M. Milner (Editor). The book explores the way in which public service 'visions' have developed globally and how successful they have been in contributing to major social and economic change. Contributions focus both on those factors critical to success and on reasons for failure, but a common theme to emerge across all contributions is the requirement for a clear political vision, commitment and leadership if the shift from traditional forms of social and economic organization to high-value, knowledge-intensive economies is to be safely negotiated. 
Electronic Governance and Electronic Democracy: Living and Working in the Wired World

http://www.amazon.com/exec/obidos/tg/detail/-/B0006E92DQ/qid=1105987495/

$\mathrm{sr}=1-6 / \mathrm{ref}=\mathrm{sr} \_1 \_6 / 103-8350796-3556619$ ? $\mathrm{v}=$ glance $\& \mathrm{~s}=$ books

A book by Thomas B Riley from Information Technology \& Globalization series.

\section{RELATED CONFERENCES, WORKSHOPS AND COURSES}

\section{International Conference on e-Government (27-28 October 2005, Lord Elgin Hotel, Ottawa, Canada)}

http://www.academic-conferences.org/iceg2005/iceg2005-home.htm

Not only is interest in e-Government continuing to grow and extend within the public service sector, but new issues - such as e-Democracy (including e-Voting) and ePolitics-are evolving. These issues are relevant to government at all levels including local, provincial, central or federal government and also at the supranational level such as the European Union. The interest in e-Government is, at least in part, driven by an agenda to radically transform the delivery of public services through the adoption of advanced information and communications technology (ICT) to make the whole process of government more effective.

\section{$5^{\text {th }}$ European Conference on e-Government (16-17 June 2005, University of Antwerp, Belgium)}

http://www.academic-conferences.org/eceg2005/eceg2005-home.htm

e-Government is clearly not only about technology - it is about reinventing the way in which public sector service providers and citizens interact. It is about enhancing the democratic processes and also about using new ideas to make lives easier for the citizen by transforming government processes, providing community leadership, enabling economic development and renewing the role of government itself in society.

\section{ECMLG 2005: The European Conference on IS Management, Leadership and Governance (7-8 July 2005, Blackhorse House, Reading University, Reading, UK)}

http://www.academic-conferences.org/ecmlg2005/2-ecmlg2005-home.htm

The Conference offers an opportunity for scholars and practitioners interested in the issues related to Management, Leadership and Governance, especially as it relates to 
the information systems field, to share their thinking and research findings. These fields of study are broadly described as including issues related to the management of information systems resources, the interface between CIOs and CEOs, the formal governance of the information systems function, the appointment and responsibility of the information systems director and the relationship between information systems management and the rest of the organization. This Conference provides a forum for discussion, collaboration and intellectual exchange for all those interested in any of these fields of research or practice.

\section{ECIW 2005: The $4^{\text {th }}$ European Conference on Information Warfare and Security (11-12 July 2005, University of Glamorgan, UK)}

http://www.academic-conferences.org/eciw2005/eciw2005-home.htm

The Fourth European Conference on Information Warfare and Security (ECIW) is an opportunity for academics, practitioners and consultants from Europe and elsewhere who are involved in the study, management, development and implementation of systems and concepts to combat information warfare or to improve information systems security to come together and exchange ideas. There are several strong strands of research and interest that are developing in the area including the understanding of threats and risks to information systems, the development of a strong security culture, as well as incident detection and post incident investigation.

\section{IEEE Symposium on Security and Privacy (8-11 May 2005, Berkeley/Oakland, California)}

http://www.ieee-security.org/TC/SP-Index.html

Since 1980, the IEEE Symposium on Security and Privacy has been the premier forum for the presentation of developments in computer security and electronic privacy, and for bringing together researchers and practitioners in the field. Papers offer novel research contributions in any aspect of computer security or electronic privacy. Papers may represent advances in the theory, design, implementation, analysis, or empirical evaluation of secure systems, either for general use or for specific application domains.

\section{IDABC: CROSS-BORDER E-GOVERNMENT SERVICES for Administrations, Businesses and Citizens}

http://europa.eu.int/idabc/en/chapter/5606

The conference "IDABC: CROSS-BORDER E-GOVERNMENT SERVICES for Administrations, Businesses and Citizens" will take place at Centre Borschette in rue 
Froissart in Brussels, Belgium on 17 and 18 February 2005. It will be open to participants from all sectors of society and address in particular associations representing citizens or industry. Participants from the public sector are also encouraged to attend since the objective of the Conference is to increase the awareness and understanding of the services citizens and businesses expect from the European public sector and to help identify the obstacles and challenges that need to be tackled to provide these. The conference discussions will help orientate and prioritise the IDABC programme's activities in support of pan-European e-Government services.

\section{Second Conference on Email and Anti-Spam (CEAS 2005)}

http://www.ceas.cc/

The conference will be held on 21 and 22 July 2005 at Stanford University, Palo Alto, CA. It is organized in cooperation with The International Association for Cryptologic Research and The IEEE Technical Committee on Security and Privacy.

\section{$18^{\text {th }}$ IEEE Computer Security Foundations Workshop (20-22 June 2005, Aix-en- Provence, France)}

http://www.lif.univ-mrs.fr/CSFW18/

For nearly two decades, the Computer Security Foundations Workshop has brought together a small group of researchers to examine foundational issues in information security. Many seminal papers and techniques were first presented at CSFW. The interest is in both new theoretical results in computer security and also in more exploratory presentations that examine open questions and raise fundamental concerns about existing theories. Panel proposals are welcome as well as papers.

\section{CSI 32 ${ }^{\text {nd }}$ Annual Computer Security Conference}

http://www.gocsi.com/annual/

The CSI $32^{\text {nd }}$ Annual Computer Security Conference \& Exhibition will be held on 1416 November 2005 in Washington, D.C. at the Marriott Wardman Park.

\section{$2^{\text {th }}$ Annual International Cryptology Conference CRYPTO 2005 (14-18 August 2005, Santa Barbara, California, USA)}

http://www.iacr.org/conferences/crypto2005/

CRYPTO 2005 will be held at the University of California, Santa Barbara. The academic program covers all aspects of cryptology. Formal proceedings, published by 
Springer-Verlag, will be provided to registered attendees at the conference. CRYPTO 2005 is sponsored by the International Association for Cryptologic Research (IACR), in cooperation with the IEEE Computer Society Technical Committee on Security and Privacy, and the Computer Science Department of the University of California, Santa Barbara.

\section{The NetSec'05 Conference}

http://www.lif.univ-mrs.fr/CSFW18/

CSI NetSec is industry network security conference. NetSec combines management topics with a technical focus to bring you cutting edge strategies and solutions. NetSec 2005 will be held on 13-15 June 2005 at The Phoenician in Scottsdale, Arizona.

\section{$12^{\text {th }}$ Annual Fast Software Encryption Workshop (ENSTA, Paris, France, 21-23} February 2005)

http://crypto.rd.francetelecom.com/fse2005/

FSE 2005 is the $12^{\text {th }}$ annual Fast Software Encryption workshop, sponsored for the fourth year by the International Association for Cryptologic Research. It focuses on symmetric cryptology and more precisely, on efficient design and cryptanalysis of block and stream ciphers, as well as hash functions and message authentication codes.

\section{EUROCRYPT 2005 (22-26 May 2005, Aarhus, Denmark)}

http://www.brics.dk/eurocrypt05/

Eurocrypt 2005 is a scientific conference that focuses on research in cryptology. It is organized by the International Association for Cryptologic Research (IACR) in cooperation with the Computer Science Department of University of Aarhus.

\section{$8^{\text {th }}$ Information Security Conference (20-23 September 2005, Singapore)}

http://isc05.i2r.a-star.edu.sg/

ISC is an annual international conference covering research and applications on information security. Continuing its past success, the conference aims to attract high quality papers in all technical aspects of information security. The conference proceedings will be published by Springer in its LNCS series. Selected papers in the proceedings will be invited for submission to a special issue of International Journal of Information Security. 
Tenth Australasian Conference on Information Security and Privacy (4-6 July 2005, Brisbane, Australia)

http://www.isrc.qut.edu.au/events/acisp2005/

Original papers pertaining to all aspects of information security and privacy are solicited for submission to the $10^{\text {th }}$ Australasian Conference on Information Security and Privacy (ACISP 2005). Papers may present theory, techniques, applications and practical experiences on a variety of topics.

\section{Workshop on Cryptographic Hardware and Embedded Systems (29 August - 1 September 2005, Edinburgh, Scotland)}

http://islab.oregonstate.edu/ches/

The focus of this workshop is on all aspects of cryptographic hardware and security in embedded systems. The workshop will be a forum of new results from the research community as well as from the industry. Of special interest are contributions that describe new methods for efficient hardware implementations and high-speed software for embedded systems, e.g., smart cards, microprocessors, DSPs, etc.

\section{IACR Calendar of Events in Cryptology}

http://www.iacr.org/events/

The IACR calendar lists events (conferences, workshops, ...) that may be of interest to IACR members or deal with research in cryptology.

\section{RELATED NEWSLETTERS, MAGAZINES AND JOURNALS}

\section{E-GOVERNMENT RELATED JOURNALS}

\section{Journal of e-Government}

http://www.egovjournal.com/

The Journal of e-Government is a new professional journal focusing on the application and practice of e-Government in its broadest sense. The Journal of e-Government is now officially affiliated with the Information Technology and Politics (ITP) section of the American Political Science Association (APSA). Papers may be on any aspect of e-Government, ranging from local to national and international initiatives and developments. Articles from practitioners of e-Government and industry experts as well as researchers in the field are welcomed. The editorial board seeks a broad range of 
case studies, research articles, reviews, and industry notes relevant to the evolving field of e-Government. Submissions are encouraged from all allied fields, including government and public administration, political science, public health, justice and law enforcement, communications, public finance, and other fields related to the use of information and communication technology in the public sector.

\section{Electronic Journal of e-Government}

http://www.ejeg.com/

The Electronic Journal of e-Government aims to publish perspectives on topics relevant to the study, implementation and management of e-Government. The journal contributes to the development of both theory and practice in the field of eGovernment. The journal accepts academically robust papers, topical articles and case studies that contribute to the area of research in, and practice of e-Government.

\section{eGovAustralia.com}

http://www.egovaustralia.com/

This is a new electronic magazine and information site covering the latest news and progress in Online Government. It features developments within both the Australian government sector and governments globally. It is an independent publication for leaders in policy, management, business development, marketing, media and IT. Subscription to eGovAustralia.com is free.

\section{E-Government Bulletin}

http://www.headstar.com/egb/

This is the website of an email service covering electronic government, teledemocracy and the information society in the UK and worldwide. The Bulletin is a free, independent publication, aimed at internet users across government, local government, the social sector and their private sector partners.

\section{PublicTechnology.net - e-Government \& IT News for the UK Public Sector} http://www.publictechnology.net/

PublicTechnology.net delivers IT and e-Government news and information for the UK public sector, focusing on IT and e-Government projects, targets, UK and EU regulations, IT best practice and case studies. Plus: UK comprehensive UK public sector directory. 


\section{Government Technology Magazine}

http://www.govtech.net/

This is the Web site for the magazine. They have an e-Government section. The user can subscribe to a newsletter to receive e-mail updates. Focus is on federal, state, and big cities but they occasionally have articles relevant to small and medium-sized communities.

\section{Government Computing Magazine}

http://www.kablenet.com/kgc.nsf/WebPagesFrontPage/gcAbout\#?expandtab=lyrKB5

Government Computing magazine is read by public sector decision makers concerned with information management and business process change. It looks at how technology can improve the delivery of public services, rather than concentrating on the technical details of the IT. Government Computing was launched in 1996 and is the longest running monthly public sector IT title. Over $60 \%$ of readers are in central and local government, whilst the rest are from executive agencies, justice, education, health and defense. Nearly $50 \%$ of its readers are top officials (chief executives, ministers, directors and deputies), $34 \%$ are senior managers (heads of department and IT managers) and the remainder is managers. The main topics covered in the magazine include: e-Content, Data protection, Freedom of information, Data storage, Communications channels, Flexible working, CRM, IT security, Integration and migration, GIS, Back office systems, Knowledge management, Business performance management, Training, Document and record management, e-Procurement, and Authentication.

\section{Governing Magazine}

http://www.governing.com/

Governing is a monthly magazine whose primary audience is state and local government officials: governors, legislators, mayors, city managers, council members and other elected, appointed and career officials. They are the men and women who set policy for and manage the day-to-day operations of cities, counties and states, as well as such governmental bodies as school boards and special districts. 
SECURITY OF INFORMATION RELATED MAGAZINES, NEWSLETTERS, NEWS SITES AND JOURNALS

\section{International Journal of Information Security}

http://link.springer.de/link/service/journals/10207/index.htm

The International Journal of Information Security is an English language international journal on research in information security. Information security builds on computer security and cryptography, but also reaches out to other branches of the information sciences. Information security is an important aspect of protecting the information society from a wide variety of threats. In this new century, The International Journal of Information Security will provide prompt publication of important technical work in information security, whether theoretical, applicable, or related to implementation. The scope of the International Journal of Information Security (IJIS) is theory, applications, and implementations of information security. This includes, but is not limited to:

- $\quad$ system security - intrusion detection, secure end systems, secure operating systems, database security, security infrastructures, security evaluation

- network security - Internet security, firewalls, mobile security, security agents, protocols, anti-virus and anti-hacker measures

- content protection - watermarking, software protection, tamper resistant software

- applications - electronic commerce, electronic government, health, telecommunications, mobility

- foundations - privacy, access control, authentication, identification, cryptography, steganography, formal methods in information security

\section{Journal of Cryptology}

http://www.iacr.org/jofc/jofc.html

http://link.springer.de/link/service/journals/00145/index.htm

Journal of Cryptology provides a forum for original results in all areas of modern information security. Both cryptography and cryptanalysis are covered, including information theoretic and complexity theoretic perspectives as well as implementation, application, and standards issues. Illustrative topics include public key and conventional algorithms and their implementations, cryptanalytic attacks, pseudo-random sequences, computational number theory, cryptographic protocols, untraceability, privacy, authentication, key management and quantum cryptography. In addition to full-length technical, survey, and historical articles, short notes are acceptable. 


\section{ACM Transactions on Information and System Security (TISSEC)}

http://www.acm.org/pubs/tissec/

TISSEC is a scholarly, scientific journal that publishes original research papers in all areas of information and system security, including technologies, systems, applications, and policies. Topics of Interest

- Security Technologies: authentication; authorization models and mechanisms; auditing and intrusion detection; cryptographic algorithms, protocols, services, and infrastructure; recovery and survivable operation; risk analysis; assurance including cryptanalysis and formal methods; penetration technologies including viruses, Trojan horses, spoofing, sniffing, cracking, and covert channels.

- Secure Systems: secure operating systems, database systems and networks; secure distributed systems including security middleware; secure web browsers, servers, and mobile code; specialized secure systems for specific application areas; interoperability, and composition.

- Security Applications: threats, system tradeoffs, and unique needs of applications; representative application areas include information systems, workflow, electronic commerce, electronic cash, copyright and intellectual property protection, telecommunications systems, wireless systems, and health care.

- Security Policies: confidentiality, integrity, availability, privacy, usage, and survivability policies; tradeoffs, conflicts and synergy among security objectives.

\section{Journal of Computer Security}

http://www.iospress.nl/html/0926227x.html

http://www.csl.sri.com/programs/security/jcs/

The Journal of Computer Security presents research and development results of lasting significance in the theory, design, implementation, analysis, and application of secure computer systems. It also provides a forum for ideas about the meaning and implications of security and privacy, particularly those with important consequences for the technical community. The journal welcomes contributions on all aspects of computer security: confidentiality, integrity, and assurance of service - that is, protection against unauthorized disclosure or modification of sensitive information, or denial of service. Of interest is a precise understanding of security policies through modelling, as well as the design and analysis of mechanisms for enforcing them, and the architectural principles of software and hardware systems implementing them. 


\section{Cipher Newsletter}

http://www.ieee-security.org/cipher.html

A Newsletter of the IEEE Committee on Security \& Privacy provides a wide range of information of current news in the field.

\section{IEEE Transactions on Dependable and Secure Computing}

http://www.computer.org/tdsc/

The IEEE Transactions on Dependable and Secure Computing publishes archival research results related to research into foundations, methodologies, and mechanisms that support the achievement - through design, modeling, and evaluation-of systems and networks that are dependable and secure to the desired degree without compromising performance. The focus will also include measurement, modeling, and simulation techniques, and foundations for jointly evaluating, verifying, and designing for performance, security, and dependability constraints.

\section{Computer Fraud \& Security}

http://www.sciencedirect.com/science/journal/13613723

Computer Fraud \& Security focuses on providing practical, usable information to effectively manage and control computer and information security within commercial organizations. Areas regularly covered include: audit and financial control methodologies, data encryption, risk management, network security, contingency planning and disaster recovery, access control, security software and software protection, authentication and validation, virus reports, and e-commerce security.

\section{Computers \& Security}

http://www.sciencedirect.com/science/journal/01674048

Computers \& Security is the official journal of Technical Committee 11 (computer security) of the International Federation of Information Processing. It is one of the most respected technical journals in the IT security field. The journal provides a unique blend of leading edge research and sound practical management advice. It is aimed at the professionals involved with computer security, audit, control and data integrity in all sectors - industry, commerce and academia.

\section{IEEE Security and Privacy Magazine}

http://www.computer.org/security/ 
Denial of service, worms, DNS, and router attacks are increasing. To help in staying one step ahead of these and other threats, the IEEE Computer Society has published a new periodical in 2003, IEEE Security \& Privacy magazine. IEEE Security \& Privacy will rethink the role and importance of networked infrastructure and help in developing lasting security solutions. Topics covered include: Wireless Security; Securing the Enterprise; Designing for Security; Infrastructure Security; Privacy Issues; Legal Issues; Digital Rights Management; Cybercrime; Intellectual Property Protection, and Piracy; The Security Profession; and Education. The primary objective of IEEE Security \& Privacy is to stimulate and track advances in information assurance and security and present these advances in a form that can be useful to a broad cross-section of the professional community-ranging from academic researchers to industry practitioners. It is intended to serve a broad readership.

\section{CyberGuard E-Newsletter}

http://www.cyberguard.com/

\section{Journal of Privacy Technology}

http://www.jopt.org/

The Journal of Privacy Technology is a refereed online journal published by the Privacy Technology Center within the Institute for Software Research International, a division of the School of Computer Science at Carnegie Mellon University in Pittsburgh, Pennsylvania. The Journal is a forum for publication of current research in privacy technology. It will consider any material dealing primarily with the technological aspects of privacy or with the privacy aspects of technology, which may include analysis of the interaction between policy and technology or the technological implications of legal decisions.

\section{Network Security}

http://www.sciencedirect.com/science/journal/13534858

Network Security is devoted to solving network security problems in system-specific detail. Every month Network Security covers: worldwide news, regular industry columns, authoritative news and analysis on the major networks and their operations and the impact on the organizations, in-depth technical feature articles, regular case studies, legal brief and Cybernet features, highlights from recent conferences, book reviews and a comprehensive calendar of events. 